\title{
GCG Gene Product
}

National Cancer Institute

\section{Source}

National Cancer Institute. GCG Gene Product. NCI Thesaurus. Code C136748.

A protein encoded by the GCG gene. 